\title{
More newcomers on the medical market, native midwives 1850-1875
}

Two days before the head of the Medical Service, W. Bosch, officially submitted a plan for the establishment of a school for doctors, he had proposed founding a school for midwives. Because the motives behind them both were identical, it can be viewed as one project. Bosch wanted to improve the medical assistance available for the population and replace the dukun with Western-trained native doctors and midwives.

\section{BACKGROUND}

The idea of training native midwives dated from the beginning of the nineteenth century. ${ }^{1}$ In the regulations of the Civil Medical Service of 1809, the municipal physicians in the three large towns (Jakarta, Semarang and Surabaya) were tasked with training indigenous women as midwives with the intention ultimately to replace the incompetent dukun bayi (Schoute 1936:39). Starting in 1817 European midwives were obliged to train native (and European) women as midwives. ${ }^{2}$ In the same year C.G.C. Reinwardt, director of Agriculture, Arts and Sciences, suggested appointing a municipal obstetrician who would assist with difficult deliveries and teach midwifery to the dukun bayi because their 'extreme ignorance and audacity still expose women in childbirth and the unborn child to the greatest mortal danger' (Historisch overzicht 1898:3). It seems none of these plans was ever carried out (Historisch overzicht 1898:3, 8).

When filling the vacancy of second municipal midwife in Jakarta in December 1836, the training of native midwives was again broached.

As early as 1807, Hull 2008:148.

De Freytag 1899:45-6. Historisch overzicht 1898:8 talks about art. 31 of the Provisioneel reglement voor den geneeskundigen dienst te Batavia en Ommelanden of 1817 that was never implemented. 
According to the head of the Medical Service, E.A. Fritze, she should be capable of teaching midwifery to indigenous women in order to meet the need for midwives in the Outer Islands. About two years later, in 1839, a suitable woman was found. ${ }^{3}$ In the meantime Fritze had been succeeded as head of the Medical Service by P.J. Godefroy, who agreed with the plan in principle. He did note three major problems, namely the costs, finding suitable indigenous women as students and the uncertainty of whether pregnant women would want to give birth in the midwifery clinic (Historisch overzicht 1898:4). The history of the school for midwives would prove Godefroy right: his objections turned out in practice to be all too real, and it is strange that they were treated so casually at the time. The resident of Jakarta had listened to his native civil servants - men of course - who were optimistic about finding suitable female students and poor pregnant women who would be willing to give birth in the clinic if the education and the treatment were free of charge (Historisch overzicht 1898:4). Most likely, these male civil servants, priyayi, had in mind female students or women in childbirth from a lower social class than themselves. The only remaining difficulty would be the cost. Godefroy sent the proposal to establish a midwifery institution with a budget estimate for advice to the Department of Finances in September 1839. ${ }^{4}$ Because the Dutch government had decided just three months earlier, in June 1839, to curtail expenses for the Netherlands Indies, ${ }^{5}$ Godefroy must not have had much faith in this advice. The outcome was actually negative (Historisch overzicht 1898:5). Ultimately, the plan did not go through because of financial objections. ${ }^{6}$

\section{MOTIVES FOR THE SCHOOL}

Although the head of the Medical Service, W. Bosch, was acquainted with this background history, he pointed out to the government in October 1847 the necessity to improve midwifery assistance for the Javanese population and proposed establishing a midwives' school for

In Resolution 24-7-1839 no. 2 she was appointed second municipal midwife, Historisch overzicht 1898:4.

Missive 12-9-1839 no. 988, Historisch overzicht 1898:4.

Resolution 17-6-1839 no. 6, Historisch overzicht 1898:8.

Resolution 1-11-1839 no. 10, Historisch overzicht 1898:5; Schoute, 1936:155. 
native girls. ${ }^{7}$ In his motivation he emphasised the ignorance of the dukun and the risks for women in childbirth and the babies. Based on his own experience as health officer in the Indies in the period 1818-1839, he could write, 'You have to have seen the ill-treatment they are subjected to at that time to understand the harm this inflicts on the population, to be able to feel what the pitiable woman is suffering!'8 The more enlightened natives called in the assistance of European midwives, Bosch continued, but the majority of the population had no other choice than to subject themselves to the rough treatment of the dukun. He reminded the government of its responsibility for 'the destruction of numerous human lives through ignorance and superstition carried out under our very eyes, with our knowledge and hence our consent'. ${ }^{9}$ The argument of population growth through better medical care, which Bosch had used for the dokter djawa school, he did not mention explicitly for the school for midwives. His successor as head of the Medical Service, G. Wassink, did employ it (Historisch overzicht 1898:17); he stressed that for him and for his predecessors Godefroy and Bosch 'the negative consequences, arising from the entirely inadequate knowledge of the indigenous midwives, concerning the natural process of normal childbirth, and their complete ignorance in deviating conditions that do occur' formed the motivation to establish a midwives' training programme (Wassink 1859b:657).

Different heads of the Medical Service thus were critical about the expertise of the dukun bayi. They were not alone in this; health officers and other European physicians had also described the horrific practices in the villages during labour supervised by a dukun. ${ }^{10}$ Descriptions are so similar they seem to have been copied. When health officer G.H.G. Harloff (1853:389) expressed a different opinion in the Geneeskundig Tijdschrift voor Nederlandsch-Indië, the editors added the following postscript to his report:

The editors feel that they must point out that this author's information only gives a tiny indication of the horrible practices applied to women in labour, by the Javanese and other populations on the islands in the

Letter 9-10-1847 no. 132, W. Bosch 1854a:197.

Letter 9-10-1847 no. 132, W. Bosch 1854a:197.

Letter 9-10-1847 no. 132, W. Bosch 1854a:197.

$10 \quad$ Harloff 1853:386; Broekmeyer 1856:40; Ludeking 1856:546-9; F. Engelken, health officer 1st class in Surakarta and Th. Keyzer, civil physician in Madiun named in Wassink 1854b:548, 558-9; Greiner 1860:650-62; Arntzenius 1867:99 -118. 
archipelago. The number who die as a result, both mothers and children, whether before, during or just after delivery, is horrifyingly high.

A more balanced image was clearly not desired. At the beginning of the twentieth century, N.A.J.F. Boerma, professor of midwifery at STOVIA, still wrote, 'I could continue listing case histories, often heartening, sometimes gruesome'. ${ }^{11}$ And P. Peverelli (1947:27), head of Health Care in the province of West Java just before the Second World War, wrote retrospectively, 'There is no topic about which so much has been written, so many case histories and horror stories reported, as midwifery'.

Most physicians in Europe also had a low opinion of midwives (Van de Borg 1992:131-9), which they took with them to the Netherlands Indies. Even in an official document like the Memorie van Toelichting (Explanatory Memorandum) for Thorbecke's legislative proposal in 1862 about the structuring of the medical sector, the following appears:

The general appreciation of the class of midwives has sunk ever further, to the detriment of society. This is one of the reasons why in some places they are sought out less, and the standard of the women who dedicate themselves to this occupation is reduced. One of the means of elevating this class would be to refuse those at the beginning who through very limited development of intellect and knowledge, or less virtuous behaviour, are not suitable for the occupation of midwife. ${ }^{12}$

In her thesis Vroedvrouwen: beeld en beroep (Midwives: image and profession, 1992), A.H. van der Borg shows that the negative image of midwives in literature does not match the real situation in several cities in the Netherlands in the period 1650-1865. Apparently, the negative stories about midwives were believed and copied without question. ${ }^{13}$ For example, at the end of the nineteenth century, the physician A. Geyl used essays from physicians and obstetricians from the seventeenth and eighteenth centuries as sources for his argument about the position of midwives. He wrote that 'the midwife of the seventeenth and eighteenth century $[. .$.$] had a low intelligence, and even lower morals, if that is$

\footnotetext{
11 Boerma 1926:233.

12 J.J. Klinkert 1980:49.

13 Schoon 1995:15 confirmed this: 'The stigma of ignorant midwives is continuously reproduced in medical history writing'.
} 
possible'. ${ }^{14}$ Physicians from the twentieth century based their writings in turn on Geyl (Van der Borg 1992:16). Van der Borg (1992:71) pointed out that the authors probably ignored the fact that only the problematic cases in the midwives' practice were recorded, producing a picture that was not representative. This applied also to the horror stories from the health officers in the Indies, who were only called in to assist when there were complications. Normal deliveries were assisted by the dukun bayi with whom the population was satisfied in general, but whose methods the government wanted to eliminate.

\section{A DELIVERY IN THE VILLAGE ${ }^{15}$}

The dukun bayi ${ }^{16}$ confirmed the pregnancy definitively once the menstrual period had skipped three months. A sacrifical meal, selamatan, was laid on, and this was repeated in the seventh month. ${ }^{17}$ After the meal the pregnant woman was smeared by the dukun bayi with seven salves on seven body parts. After she washed herself, the water barrel was smashed to encourage a birth that would be as easy as the breaking of the barrel. The future father also had to conduct ritual acts. To promote an easy birth, he had to cut off the band wrapped around his wife's middle. Once the woman was dressed for the festivities, she returned to the guests for an auction, the proceeds of which were intended for the future child. All of this took place under the watchful eye of the dukun bayi. Often the day would conclude with a wayang show with a suitable subject such as the birth of a mythological hero. ${ }^{18}$

Once the first labour pains began, several female family members and neighbours would gather along with the dukun bayi. The dukun massaged the pregnant woman and placed a band loosely around the woman's

\footnotetext{
14 Van Lieburg 1987:12.

15 Mayer (1894:114-60) provides a detailed description of this. His description of a delivery and the associated aftercare broadly agrees with that by J. Idsinga, CMS inspector. See his letter to the head of the Medical Service of 11-11-1876 no. 28, Historisch overzicht 1898:appendix B; unless specified otherwise, they are the sources in this section.

16 Traditional midwives were called dukun bayi or dukun beranak on Java, paraji among the Sundanese and dukun rembliq among the Madurese. For the sake of simplicity, I shall just use dukun bayi. Today we use the term TBA (traditional birth attendant).

17 Sometimes a selamatan was already held in the second month; sometimes a selamatan was organised every month after the first selamatan.

18 The 7-month ceremony is still important, Heringa 2007:24-54.
} 
stomach. To ward off evil spirits, her belly and limbs were rubbed with herbs; garlic and other things were hung in the entrance of the house while the dukun recited prayers. The husband was present at the birth and had to support his wife's head and back. If the husband was hindered, he would be represented at the bedside by a rice pestle or a bolster dressed like a doll. The family members and neighbours were tasked with making sure that the woman in labour did not scream. It was considered disgraceful to announce the product of something created in silence by screaming to the world. During the labour pains the dukun provided care by exerting pressure, sometimes by pulling the abdominal band tighter, so that the child would not shoot backwards; when the dukun became tired, the bystanders would help out. The amniotic fluid was considered the older brother or sister of the child, and the placenta the younger. The dukun was only allowed to cut the umbilical cord with a bamboo knife after the placenta had been expelled, and then she bathed the baby. Once the navel had been treated and covered with an umbilical bandage, the child was wrapped in swaddling clothes. Only then did the dukun bayi turn her attention to the mother: she was bathed, rubbed with herbs, and her abdomen tightly girded. Finally, the dukun bayi dealt with the placenta: it was washed, wrapped in leaves and buried or thrown in the river along with objects to bring the baby good fortune, for example, salt so that he would never lack anything. The mother applied creams and drank concoctions for 40 days after the birth to restore the blood circulation. During that period her abdomen was massaged by the dukun bayi to restore it to its original shape. On the 40th day after the birth, the woman was bathed and examined by the dukun bayi and after dressing was ceremoniously returned to her husband by the dukun, after which she received the agreed compensation for her work. At certain moments, such as immediately after birth, when the umbilical cord falls off, for the name giving ceremony, and at the appearance of the first tooth, a selamatan is held, to which the dukun bayi is always invited. She is also the one who places the child with his feet on the ground for the first time, and that is also accompanied by a selamatan. The dukun bayi often remained to help out for 40 days, not only caring for the mother and child but also doing household chores. ${ }^{19}$

Of course, complications sometimes occurred during deliveries. If the start of labour was delayed, the dukun bayi gave the woman in

19 After about 40 days the uterus has returned to its original shape and the young mother can carry out heavy work again. It is thus a logical cut-off point. 
labour an astringent drink that was thought to promote the childbirth process or tried through manipulating the abdomen to push the child out. She would also order all doors and windows to be opened, in the hope that the cervix would follow suit. ${ }^{20}$ With massage she could reposition the baby correctly. If the delivery was very difficult, more dukun would be called in, including sometimes a male one with magical powers (Verdoorn 1941:75). If the delivery of the placenta was delayed, nothing would be done for the mother or child, even though both had to lie for hours, sometimes days, in a pool of blood. The dukun would try with massage or pulling on the umbilical cord to draw the placenta out. The fear was that it would remain in the womb if the umbilical cord was cut immediately after delivery. The newborn would not then be complete without its brother or sister (Kleiweg de Zwaan 1910:34). Only if the mother died during childbirth would the umbilical cord be cut earlier. Then it was assumed that the placenta, still in the mother's body, did not want to have anything to do with the baby.

\section{POSITION OF THE DUKUN BAYI}

Modern scholars can give us an impression of the position of the dukun bayi in society. In the beginning of the 1970s, a large-scale survey was conducted in Serpong, a district in West Java. ${ }^{21}$ The district had about 55,500 inhabitants at that time spread over 15 villages. Almost all deliveries, $96 \%$, were supervised by 77 dukun bayi, who grew crops as well as supervised deliveries. They were a bit better off than average and were respected by the population. Their specialist knowledge had often been passed down to them by their mother or grandmother and gained through experience; only two dukun bayi could read. They were all married when they became dukun bayi, had already had children and were somewhat older. Most of them started working from the selamatan in the seventh month of pregnancy. Three-quarters of them used a bamboo knife when cutting the umbilical cord. For complications like retention of the placenta, the majority knew only to recite magical formulas; onethird would apply massage. Almost all of them gave postnatal care, like

\footnotetext{
2o The exact same procedure was employed in the Netherlands at the beginning of the $20^{\text {th }}$ century, Marland 1995:72.

${ }_{21} \quad$ The Inter-university family planning research and training scheme.
} 
massaging the mother and prescribing medicinal herbs. ${ }^{22}$ This situation in Serpong did not differ from what Eric A. Stein (2007:58-9) encountered at the beginning of the twenty-first century in the rural countryside of Banyumas (Central Java), where the population respected the dukun bayi for her knowledge of the authentic midwifery (asli). In both cases the dukun bayi seems strongly embedded in society, and her working method has hardly been affected by Western medicine. The practice of the dukun bayi as described by modern anthropologists seems unchanged compared with the nineteenth-century sources. Their position in society probably did not change much either. They could not have lived from their compensation, usually 'one, two, at most three guilders, sometimes a few farthings, or ... a chicken, a sarong, a rug or just ... a cup of coffee, a sirih plum, one or a half gantang [about 1.5 kilo] rice';23 they received 16 cents per delivery in the Priangan in 1867 (Historisch overzicht 1898:28).

\section{DECISION-MAKING}

To replace the dukun bayi, W. Bosch wanted to train native women as midwives. He proposed establishing a midwifery clinic in Jakarta or Semarang for 20 students. ${ }^{24}$ The situation in the Netherlands, where the first midwives' school was established in 1861, could hardly have formed an inspiration. Within a month of submitting his proposal, Bosch heard that the government would permit an experiment if the costs were kept to a minimum. They also asked for more details. ${ }^{25}$ After Bosch supplied the requested information, including a budget of $f 18,000$ for the building, the government started formulating objections. While the utility of the training programme was acknowledged, the costs were too high, and there was doubt about whether one clinic would be enough. The government produced another option: the training of soldiers' wives and concubines in all major garrisons. ${ }^{26}$ Bosch rejected this plan; he felt that only a small number of health officers were competent to provide this training, and thus a training programme in every major garrison would

$22 \quad$ Lubis, Borkent-Niehof and Pudji Astuti 1973.

23 Report for 1861, Historisch overzicht 1898:18; one gantang cost 50 cents.

24 Archief Schoute Batavia, October 1847.

${ }_{25} \quad$ Letter from general-secretary 5-11-1847 no. 2491, Historisch overzicht 1898:6.

${ }_{26}$ Cabinet letter 2-5-1848 no. 106, Historisch overzicht 1898:7. 
not be feasible. Most health officers were trained in the Rijkskweekschool voor Militaire Geneeskundigen in Utrecht, where midwifery was not included in the curriculum. Apart from that, Bosch felt that the soldiers' wives and concubines were not sufficiently educated to follow a theoretical programme. In addition, each garrison would have to have expensive, educational equipment such as a manikin. ${ }^{27}$ It would thus be an expensive option (Historisch overzicht 1898:8).

Bosch's counterarguments appeared to convince the government because he was commissioned during his next inspection tour of Java to talk about the future midwives' school and ascertain whether the municipal midwives in Jakarta, Semarang and Surabaya would be able to provide the training programme (Historisch overzicht 1898:8). Apparently, he did not encounter any insurmountable objections during his tour, and the next step was initiated: in January 1850 a request for advice was sent to the Council of the Indies. It involved a trial, and only one training programme was mentioned instead of the original three. ${ }^{28}$ The Council's resolution was positive, and in June 1850 the governor-general gave his approval. ${ }^{29}$ In contrast to when the dokter djawa school was being established, the governor-general could now apparently take a decision without the government in The Hague, perhaps because it was a trial. The budget restrictions in effect for the Netherlands Indies, which had led to a similar proposal from Godefroy in 1839 being rejected, no longer formed an obstacle.

\section{THE SCHOOL}

The school for native midwives was located on the grounds of the military hospital in Jakarta - as was the dokter djawa school. Both training programmes were free, and the girls received an allowance of $f 12$ per month for food and clothing, the same amount as a servant's wage (Historisch overzicht 1898:7). After the school and the maternity ward were built, the programme started in October 1851.30

\footnotetext{
${ }_{27}$ This is a model of the female body from the waist downwards with which students could practise assisting deliveries using a doll; it is still being used for training programmes today.

$28 \quad$ Archief Schoute Batavia.

$29 \quad K V$ 1850:39: 'The Resolution of 12-6-1850 specified that trials shall be done for the training of native women in practical midwifery'.

3o In the letter of 2-8-1852 no. 612, Bosch reported on the results of the past 10 months, Historisch overzicht 1898:10. This allows us to estimate that the school began in October 1851.
} 


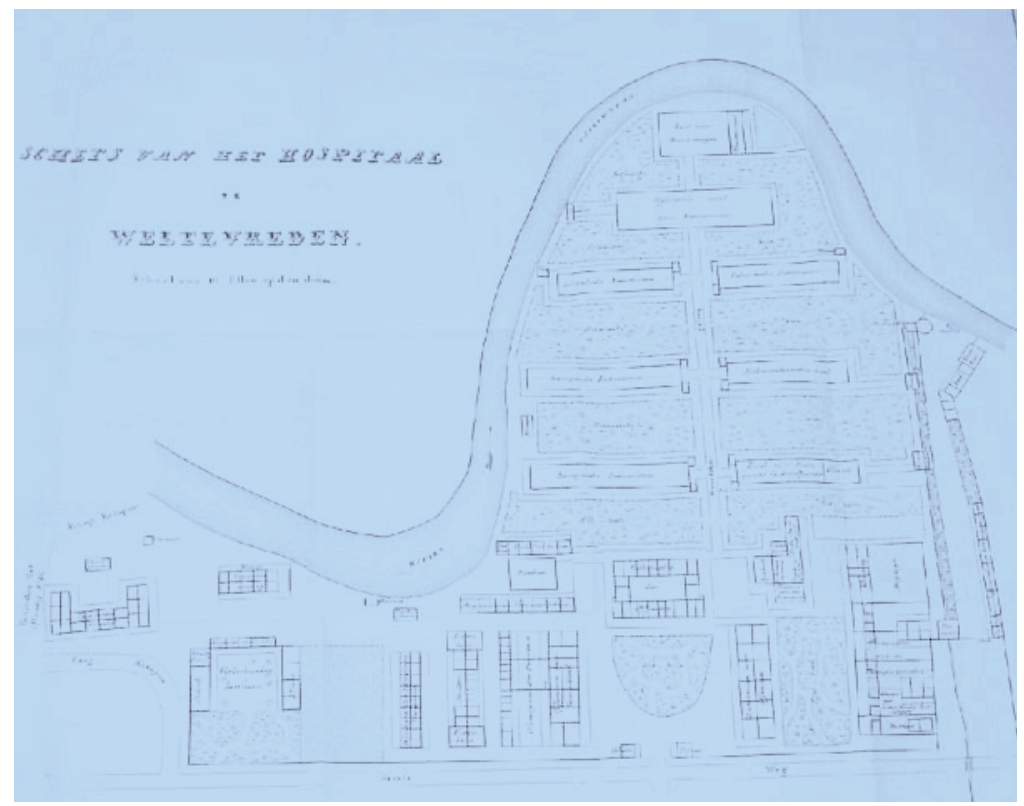

The school for midwives is on the left in a rather secluded part of the grounds of the military hospital. Just to the right are the dormitories for the students of the dokter djawa school; their theoretical courses were given in the school located even farther to the right. (GTNI 1856:119.)

\section{GURRICULUM}

The curriculum consisted of occupational subjects: 'describing the human skeleton in general and the pelvis in particular; the principles of human physiology; the various dimensions of the female pelvis; the theory of pregnancy and the ovum; the natural and unnatural positions of the fetus and various practical rules' (Wassink 1859b:658). Strangely enough, in 1850 it was assumed that the students could read, write and do arithmetic, as part of the teaching was theoretical. Bosch and the government should have known better. The educational possibilities were limited, especially for native girls. It was actually amazing that one of the 20 students of the first cohort had learned to read and write at least the Javanese alphabet (Historisch overzicht 1898:10). Up until the school for midwives closed in 1875, the vast majority of students had not 


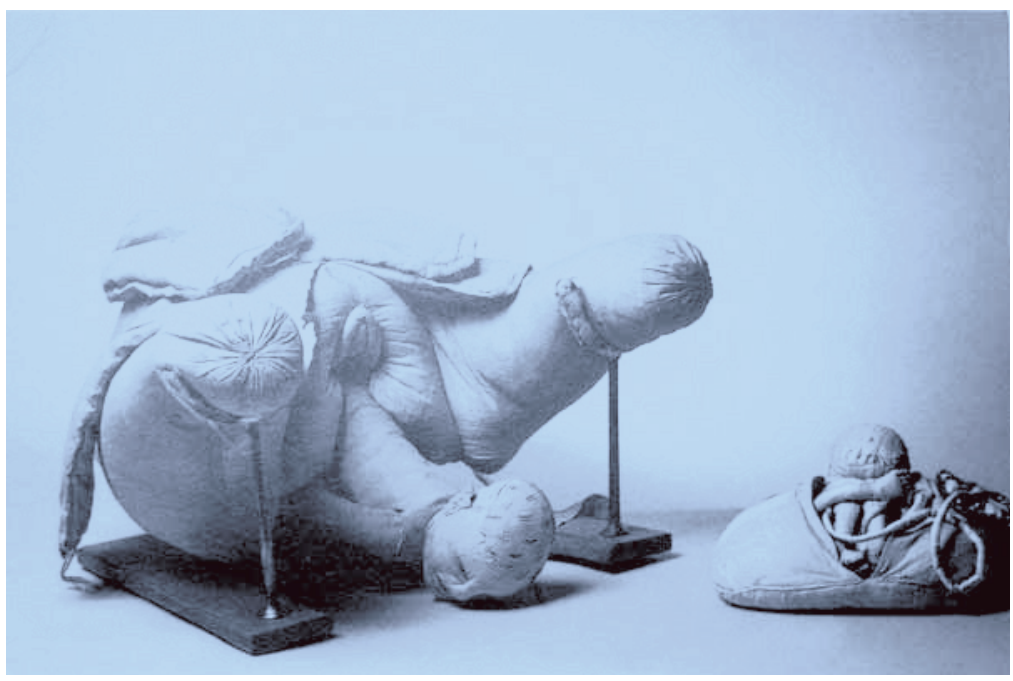

A manikin. This is a model from the 18th century, but it originates from France, like the midwives' school model. (postcard from the author's collection)

even undergone elementary education upon admission (Historisch overzicht 1898:14). The training programme was intended to last $1 \frac{1}{2}$ years; ${ }^{31}$ but in practice most students took longer (21/2 to 3 years) (Historisch overzicht 1898:14) because they had to learn to read and write and do arithmetic first (Wassink 1859b:657).

For the dokter djawa school, the language of instruction was repeatedly discussed. The teachers were assumed to have such a limited command of Malay that they could not use it for teaching. Just before the midwives' school was opened, a municipal midwife in Jakarta confirmed that she did not speak enough Malay to give lessons in it (Historisch overzicht 1898:8-9). After the school was established, however, nothing more was heard on this topic.

Along with theory the students had practical lessons. They used a manikin and the Atlas d'obstétrique by Moreau, which were both ordered from Paris. ${ }^{32}$ The Atlas by Moreau was considered the most beautiful in the nineteenth century. ${ }^{33}$ Clearly, no budget restrictions were imposed on

\footnotetext{
$3^{1} \quad$ According to Historisch overzicht 1898:10, one year.

$3^{2} \quad$ Archief Schoute Batavia.

33 www.vialibri.net.
} 
these teaching materials, although the government usually held tight to the pursestrings. Practical experience was gained by assisting women in childbirth under supervision.

\section{PREGNANT WOMEN}

An essential ingredient for the practical training was the availability of pregnant women. In its first response to Bosch's proposal in 1847, the government doubted whether, 'given the population's attachment to its own house and tools [probably this referred to the dukun bayi], twelve pregnant women at regular intervals would be willing to allow themselves to be cared for in the institution'. ${ }^{34}$ Bosch thought that this objection would disappear when soldiers' wives and concubines were considered in the group of pregnant women (Historisch overzicht 1898:7).

In the Netherlands Indies army, the soldiers lived with their families in the barracks. They slept in large halls, where every soldier and his wife/concubine could screen their 'sleeping table' with cloths. The children lay under the sleeping table (Bosma and Raben 2008:245). Women and children were thus part of barracks life. There was no designated place for giving birth, and, according to Bosch, deliveries in the barracks led to 'the most shocking scenes', and mother and child got no rest. He expected that soldiers' wives and concubines would be happy to make use of the maternity clinic because they would be treated decently there, and be fed, cleaned and allowed to rest. He also proposed giving each woman in labour a bonus of ten guilders after she recovered. This bonus would only be needed in the beginning because he estimated there would always be pregnant women (Historisch overzicht 1898:7). He would be proved right in this. The bonus could already be halved by the end of 1853 (Historisch overzicht 1898:11). According to the head of the Medical Service, G. Wassink (1859b:664), often more pregnant women applied than could be accommodated. Although he was rather overly positive about the school for midwives, this time he appears not to have been exaggerating. In 1872, when the school had just 7 students, 46 pregnant women were admitted. In total, between 1852 and 1872, 1128 women in childbirth were nursed in the clinic. For the total of 142 students 
in the same period, that seems an ample number (Historisch overzicht 1898:13-4).

\section{SCHOOL MANAGEMENT}

During the entire existence of the school, almost 25 years, it was run by H.J. Zembsch-de Klemp. ${ }^{35}$ That she was listed in the sources as a teacher and not the director may be due to the often disparaging attitude of European physicians towards midwives. ${ }^{36}$ This can be heard in the words of the Commission charged in 1906 with the reorganisation of the colonial Medical Service: 'How is it otherwise possible that someone had the idea of instructing a midwife with a European diploma to teach native midwives, even to let them carry out obstetric methods'. The Commission suspected that the explanation lay in the fact that the health officers did not have any training in midwifery (Bijker et al. 1908:89).

Zembsch's work in the school was a supplementary job in addition to her position as second municipal midwife in Jakarta. She received a monthly allowance of $f 100$ for it, the same as her usual salary, ${ }^{37}$ thus doubling her income. In comparison, the municipal midwives in the Netherlands were far worse off: their annual salary was roughly the same as a month's salary of their colleagues in Jakarta. ${ }^{38}$ It was even more amazing that in 1853, Zembsch's allowance was raised to the enormous sum of 150 guilders per month (Wassink 1859b:657, 659).

Zembsch had the task of preparing the students for their future work situation although she had no experience assisting at the deliveries of indigenous women. Her colleague, the first municipal midwife, A.J. Redeker-Pulle, assisted at 1410 deliveries in 20 years (1835-1855), including 1342 Europeans, 55 Chinese and 13 Natives (Bosch 1854b:328). Assuming that Zembsch's practice as second municipal midwife had a similar composition, she would also have rarely seen native patients. It is thus debatable whether she could prepare the students for a delivery

\footnotetext{
35 Her husband, Johannes Paulus Zembsch, was a physician in Batavia. He died in 1850 on the way back to the Netherlands where he intended to recuperate from his illness. His widow returned to the Indies after an interval as a municipal midwife. She died in Jakarta in 1887. Her two children had no offspring, CBG, The Hague.

$3^{6}$ Appointment by disposition GG 14-4-1852 no. V, named in the letter from the director of Education, Religion and Industry, W.A. Henny, to GG 25-8-1875 no. 9086, Archief Schoute Batavia 1875.

37 Resolution 12-6-1850 no. 3, KV 1850:39.

$3^{8} \quad$ In the same period municipal midwives in the Netherlands earned 100 to 150 guilders per year, Van der Borg 1992:115.
} 
in a village with all the associated customs. But perhaps this objection is irrelevant because the students were expected to follow a Western training programme.

\section{STUDENTS}

The school was planned for a maximum of 20 students (Borgers 1941:121). After the proposal for the training programme had been approved, it was crucial to have enough suitably qualified students. Little is known about the recruitment method. ${ }^{39}$ The local administrators were meant to intercede to recruit students from different residencies, especially from the principal towns of the districts. Once they graduated, they were expected to return home (Historisch overzicht 1898:6). It was thought that the graduates would be able to build up their own practice better in the district capitals than in a village. The regional government would often have turned for help with the recruitment to the native administrators, who had their own opinions about education for women and would certainly not have considered it suitable for women from their own social class, the priyayi. Also for women from the lower social classes, a long training programme far from home, organised by the government, was problematic. In addition, it was known that in Islamic circles, certainly in orthodox ones, there were serious objections to girls attending school. ${ }^{40}$ For example, no students from the residency of Banyuwangi were ever sent to the midwives' course because the regent was 'pure Mohammedan' and anti-European (Historisch overzicht 1898:22).

From the beginning attempts were made in different districts to attract students, who would return to their region of origin after the training programme. In contrast to the dokter djawa school, the midwives' training programme was never intended specifically for Javanese women and girls. Given the enormous distances, it is remarkable that students from the Outer Islands applied: one of the ten students who graduated in 1854 came from Padang (Sumatra's West Coast) and returned there. ${ }^{41}$

\footnotetext{
39 The residents had agreed that for the school for surveyors in Cirebon, each regency would delegate one student, Algemeen verslag onderwijs 1855:188-9. It is likely that a similar agreement was made regarding the recruitment for the school for midwives.

$4^{\circ} \quad$ In 1900 a survey commissioned by Director of Education, Religion and Industry Abendanon still revealed that the indigenous society in general wanted to have absolutely nothing to do with education for girls, De Kat Angelino 1931b:251.

$4^{1} \quad$ Wassink 1856:799; KV 1854:60.
} 
In 1857 all ten new students came from the Outer Islands (Wassink 1859b:660). Of the 142 students who attended the school, 39 came from the Outer Islands, about 27\% (Historisch overzicht 1898:14).

Bosch had rejected the idea from the government to admit soldiers' wives and concubines to the training programme because they had too little development and refinement. Attracting better educated young women seemed to be impossible, however. Even Wassink, who strongly supported the midwives' school, reported that the students in general came from the lowest class of society (Wassink 1859b:663). The names of the students we know confirm this: simple names without titles, while many of the dokter djawa had titles such as mas or raden. For the Europeans it was expected that the students would come from the lowest class because this was the same situation in the Netherlands (Van der Borg 1992:135). Perhaps that is why the resident of Tegal wanted to enrol 15 prostitutes. Bosch made it clear that this type of student was not wanted, as they would sabotage the aim of the training programme (Historisch overzicht 1898:9). A similar 'offer' came from the Priangan where the resident enrolled several ronggeng (Historisch overzicht 1898:10), dancers who were often prostitutes. ${ }^{42}$ It is known that two graduates were ronggeng: one from Rembang and one from Banyumas. ${ }^{43}$ There were no further reports about former ronggeng from the Priangan; probably they were not admitted to the training programme. And few students of (Indo-) European origin attended the school. ${ }^{44}$

\section{MARITAL STATUS AND BEHAVIOUR}

Married students were admitted, but their husbands were not permitted to stay overnight. ${ }^{45}$ Even when in 1866 married women were recruited specifically, an express condition was that husbands and children would not reside in the school. ${ }^{46}$ Usually, the husband stayed at home; it was relatively common in those days for one of the partners to be absent

\footnotetext{
$4^{2} \quad$ According to De Braconier 1919:512 they were highly respected by the public; according to Dansen 1917:571 they did not lead a virtuous life.

43 Respectively, Historisch overzicht 1898:24 and Archief Schoute Banjoemas, 1858.

44 An orphan from Sumatra's West Coast, the daughter of a retired sergeant in Cirebon, Historisch overzicht 1898:13. Also, midwives with names like Teuntje van Bommel, Johanna Robberts and Wilhelmina Mausbach must have been of (Indo-)European origin.

45 In the first cohort there were definitely two married candidates, namely from Banyumas and from Semarang; the latter had a child, Historisch overzicht 1898:10.

${ }_{4}^{6} \quad$ Circular 30-1-1866 no. 167, Historisch overzicht 1898:14 note 1, 30-1.
} 
for long periods because of work. The husband could try to get a job in Jakarta, for example as an orderly in the military hospital. ${ }^{47}$ Sometimes the woman was married to a student of the dokter djawa school. This could probably be arranged in the recruitment process: if one of the partners was interested in the training programme in Jakarta, the other would be approached for the other course. At the dokter djawa school the students were only allowed to be married if their spouse was a student in the midwives' training programme (Lauw 1987:82). Only once was an explicit reference made to a Sumatran trainee midwife who was married to a future dokter djawa. 48

The students of the dokter djawa school had to present proof of good conduct upon admission (Lauw 1987:82). It is not known whether the midwives' school had a similar criterion. Certainly the conduct of the students and graduates was a matter of great concern. Perhaps it was assumed that people from the lower classes were generally badly behaved, but people could also have been concerned because they were young women. The authorities would have been aware that the midwives' behaviour - and thus the students' - was an essential component of the success of the project. Within the indigenous community, the graduates had to earn a certain status, even if only to be able to compete with the greatly respected dukun bayi.

The first report about the training programme in 1852 was already full of praise for the students' behaviour: 'They do not take advantage of the opportunity to go out; they live very modestly and demurely, which is ascribed partly to the strict supervision and partly to the edifying effect of education and regular employment' (Historisch overzicht 1898:11). Perhaps this remark was meant as a signal for the regional administrators that they could recruit decent young women without hesitation and that they did not have to present prostitutes and dancing girls. A few years later, in 1859, the words of Head of the Medical Service Wassink (1859b: 663-4) expressed a certain admiration for the students:

Regarding the students' moral behaviour, one can be astonished at how quickly they adjust to conditions so different from those they used to

\footnotetext{
47 Historisch overzicht 1898:10; the husband of Sariëm, student in 1864-67, was a servant to G. Wassink, Historisch overzicht 1898:44.

$4^{8} \quad$ Letter from J. van Swieten 24-12-1863, in: NA, Koloniën, 1850-1900, 2.10.02, inv. no. 1433, Vb. 27-1-1864 no. 18.
} 
live in, given their age, previous social status, education, etc. Although there are opportunities to do so, they rarely go out; it seems that these women, aware of what they were and what they can become, choose a modest, home-loving life above so-called entertainment. [...]. This reporter ascribes the model behaviour of the students to the realisation that they have of their previous status and of what they could achieve with diligence and attentiveness, to appropriate supervision, to steady employment requiring reflection and examination and laying the foundation of order, which in turn engenders pride.

The quotations reveal that behaviour was associated with morality and that a double standard governed the sexual behaviour of women and men. Although it is not known whether there was much to say about the behaviour (sexual or otherwise) of the students, the head of the Medical Service, A.E. Waszklewicz, expressly requested in 1866 recruiting married women to avoid immoral behaviour. He was a strong supporter of the midwives' training programme, but apparently their behaviour was a point of concern for him. Of the 142 students between 1851 and 1872, 14 were sent away for misconduct. Together with 20 students who were sent away because they were unsuitable, the percentage of dismissed students was 24\% (Historisch overzicht_1898:14). At the dokter djawa school 72 of the 256 students from the start until February 1873 were dismissed because of unsuitability or misconduct, ${ }^{49}$ or $28 \%$. The loss because of misconduct and/or unsuitability was about the same for both training programmes, but because no distinction was made between misconduct and unsuitability in the dokter djawa school, it cannot be determined whether misconduct was noted more often among the young women than among the young men.

\section{EARLY PRAISE}

Just like with the dokter djawa school, those directly involved in the midwives' training programme quickly presented a positive picture. Perhaps it was meant to stimulate recruitment or from fear that the government might abolish the funding. Examples of early commendation can be 
found in the report from mid-July 1852 by Wassink, who as commanding health officer $1^{\text {st }}$ class was charged with supervising the school. ${ }^{50} \mathrm{He}$ reported that several illiterate students from the first cohort had learned to multiply figures with twelve numbers and zeroes in just ten months (Historisch overzicht 1898:10). This is almost brilliant, but the question is what use would it have been to a prospective midwife? He probably wanted to stress that lack of prior education did not present a problem. In October 1853 Bosch attended the final examination of the students from the first cohort, after which he reported to the governor-general that both the theoretical and the practical knowledge completely met the expectations and achieved the aim. 'These women have demonstrated using the manikin that they are capable of providing obstetric assistance, in both natural and difficult deliveries - if necessary by applying forceps' ${ }^{51}$ Bosch was generous with his praise not only of the students' achievements but also of the training programme; he wrote with some exaggeration, Already and despite the fact that the native midwives must sometimes fight against the prejudice of the population, it can certainly be assumed that many a mother and child were spared, who without the assistance of these midwives would have been the victims of the rough empiricism of the so-called dukun'. ${ }^{52}$ The new graduates had attended deliveries during their study and under supervision, but it is going too far to state that they saved many lives by doing so. The editorial board of the Geneeskundig Tijdschrift voor Nederlandsch-Indië was also full of praise for the school in 1853, two years after its establishment: it 'already promises the most splendid results for the future'. ${ }^{53}$

Bosch's successor Wassink (1859b:663) continued in the same vein: the students learned to read and write in Malay and do algebraic calculations in six to ten months, ${ }^{54}$ and they progressed well in theoretical midwifery. This also sounds too good to be true. In his reports Wassink (1856:799) effusively praised the students and the training programme: 'The midwifery institute, which is already posting good results after such

\footnotetext{
$5^{\circ}$ In the articles of association in June 1850, Bosch was commissioned to report on the examination procedure on 1-7-1852. In practice, Wassink was the one who prepared the report that Bosch published on 2-8-1852 no. 612, Historisch overzicht 1898:9, 10.

$5^{11} \quad$ Letter from Bosch to GG 21-10-1853 no. 877, Secret Archive of the general-secretary, Archief Schoute Batavia.

$5^{2} \quad$ Letter from Bosch to GG 21-10-1853 no. 877, Secret Archive of the general-secretary, Archief Schoute Batavia.

53 Addition from the editorial board at the end of Harloff 1853:389.

$54 \quad$ This refers to equations like 4:2 = 8:x.
} 
a short existence, also excels in its cleanliness and good order and the rapid progress of its students in the subject of midwifery'. A year later Wassink (1857:1120-1) was no less enthusiastic:

It is worth remarking that both the school for native doctors and that for midwives continue to produce favourable results. Already now, after such a short existence of the training programme for native midwives, the usefulness of the graduates is proclaimed loudly from various sources, and there is no doubt that as the suitability and expertise of these women develop and become better known, the prejudice prevalent among so many so-called indigenous children [referring to potential students] and among the indigenous population in particular against European midwifery assistance will be increasingly counterbalanced, and science triumphs here, too, someday over the rough empiricism, if that is what one can call the exercise of midwifery by dukun, who each year put a number of mothers and children in their graves.

Later he repeated his message, but now in his function as chief editor of the Geneeskundig Tijdschrift voor Nederlandsch-Indië:

As I have repeatedly remarked, the conviction that many lives are lost due to the lack of expert assistance during childbirth led to the establishment of an institution in the main hospital in Jakarta in which native women are trained in midwifery at government expense. It is thus only fair to expect that in several years' time the results of the training will not only fulfil the aim but will also yield sufficient interest to amply compensate the capital invested by the government in the establishment and maintenance of that institution..$^{55}$

Others also hoped that the graduates would ultimately replace the incompetent dukun. For example, E.W.A. Ludeking (1856:548), health officer in Padang (Sumatra's West Coast), complained in 1856:

It is widely known that indigenous women, during childbirth, prefer indigenous assistance to that from a European physician. That is why we can only praise the existence of a midwifery institute for native women 
in Jakarta as most fortunate and appropriate, to prevent cases like the ones reported here. The midwives trained there, born to the population and armed as far as possible with the knowledge of obstetrical science, remove the listed objections entirely.

Similar comments were made ten years later by A.K. Arntzenius (1867:99-118), health officer in Buru (Moluccas), after he was called to a delivery far too late. Even a soldier like A.W.P. Weitzel (1860:34-5), who visited the Indies only briefly, ${ }^{56}$ had high expectations of the school for midwives: it was destined 'to spread the richest blessings over Java someday'. There was a great need to bring to an end 'the sometimes gruesome actions [...] that are often taken on Java during the delivery of women in childbirth because of superstition or ignorance'. In brief, the necessity for Western-trained midwives was expressed in all types of ways.

\section{THE GRADUATES AND THEIR TASKS, $1855^{-1865}$}

There were extensive discussions about whether the dokter djawa should become a vaccinator or an assistant-doctor, as we saw in chapter 4 . But from the beginning, everyone assumed that the graduates of the midwives' school would work as midwives among the population to replace the incompetent dukun bayi. In the discussion about the position of the dokter djawa, their term of address came up. It is not clear how the certified midwives were addressed. Official documents refer consistently to 'native midwives', but this is not a proper term of address. In a report from 1856, a certified midwife in Pasuruan was called 'orang beranak' (Wassink 1859a:111), perhaps analogous to dukun beranak, a synonym for dukun bayi. The term of address for two sucessfully employed graduates is known: Sariëm was called 'doctor prampoean' (Historisch overzicht 1898:44), literally female doctor, Nji Astijem called herself 'government midwife', ${ }^{57}$ probably to stress her link with and support from the government. Elsewhere we find similar designations, such as 'orang Gouvernement' for midwives who received an allowance from the government. ${ }^{58}$ There was evidently no official name for the native midwives.

\footnotetext{
$5^{6}$ From 1853-60 he was minister of War and of Colonies, Van 't Veer 1985:15.

57 Historisch overzicht 1898:appendix A.

${ }_{5}^{8} \quad$ Historisch overzicht 1898:18 (circa 1861).
} 
Just like the dokter djawa the midwives were expected to return to their region of origin to start work after graduating. Both groups were supervised by the physician responsible for the Civil Medical Service (Ind. Stb. 1856 no. 70). There was a subtle difference: while the physicians were meant to promote the further development of the dokter djawa, this was not considered necessary for the midwives. Almost all graduates found work in their region of origin. Teuntje van Bommel, Johanna Robberts, Wilhelmina Mausbach and Sima were exceptions, all graduates in 1856 (Wassink 1859b:659). Two of them found posts working for the indigenous rulers of Surakarta and Yogyakarta; the other two departed for Probolinggo and Besuki because no Western midwifery assistance was available in those residencies, and attempts to recruit students had not been successful (Wassink 1859b:660). The latter argument is surprising because there were many residencies that had not yet successfully managed to recruit students; after all, the school had only been open for a few years.

We have some insight into the work of a few graduates. A midwife in Pasuruan assisted at 19 deliveries in three months (Wassink 1859a:111), equivalent to 76 deliveries per year. Two midwives in the regency of Garut (Priangan) and the two European municipal midwives in Jakarta assisted at 111 and 133 deliveries, respectively, in one year, ${ }^{59}$ which is equivalent to 55 to 66 deliveries per midwife per year. Alida Koerong, a native midwife in Jakarta, assisted at 39 deliveries in the first year after graduating, 1858 (Schoute 1936:335). ${ }^{60}$ In comparison: dukun bayi assisted at an average of 20 deliveries per year (Verdoorn 1941:120).

\section{RESISTANCE}

The graduates were thus meant to build up their practice among the indigenous population. Cognescenti such as Head of the Medical Service Wassink (1859b:662) understood all too well that this would not be simple: 'This is not the place to go into detail of how difficult it is to sweep aside the public prejudices rooted in superstition, ignorance and customs'. Several residents indicated in their annual reports that the

\footnotetext{
59 Respectively, resident of Priangan 1867-68, Historisch overzicht 1898:28; Wassink 1855:366.

6o In 1910 Dutch midwives assisted at 110 deliveries per year on average, a much higher average than in neighbouring countries, Marland 1995:67-87.
} 
population had little faith in the Western-trained native midwives. ${ }^{61}$ The resistance was partly associated with that against Western medicine in general. ${ }^{62}$ The aversion was primarily due to the population's unwillingness to let go of old customs, an implicit referral to the adat (Historisch overzicht 1898:26).

In the comparison between a dukun bayi and a certified midwife, the population preferred the former for several reasons: her age, methods, behaviour (moral) and - literally and figuratively - proximity. For example, the midwife in Banyumas was not in favour because of 'the Javanese superstition that a midwife must have grey hair to be skilful'. ${ }^{63}$ This argument was often cited. ${ }^{64}$ Dukun bayi derived their reputation from their usually advanced age, which meant that not only had they assisted at many deliveries, they were mothers who had had several children and knew the intimate details of childbirth. ${ }^{65}$ The population was also adverse to the European delivery method (called expectative midwifery); 66 the certified midwives at standard deliveries did not interfere but let nature take its course, which worried the population. ${ }^{67}$

Furthermore, the alleged immoral conduct of the certified midwives produced resistance. Examples of bad behaviour included living together with a European, like a midwife in Bangka (Historisch overzicht 1898:23). During one of his inspection tours, the Civil Medical Service inspector, FJ. Cornelissen, heard from Sariëm, a certified midwife in Purworejo (Bagelen), that of the 56 graduates only herself and three others were married, the others had 'mostly chosen to leave the straight and narrow and were living with Chinese and Europeans' (Historisch overzicht 1898:44). Such a testimony from an insider was probably taken very seriously; the inspector repeated it in a report years later. It is curious, though, that Sariëm in Purworejo could be so well informed about the situation of her colleagues spread throughout the archipelago. The resident of the Priangan could understand how such relationships came to be. 'It is not

\footnotetext{
$61 \quad$ Archief Schoute Bagelen 1855, Kedoe 1856, Banjoemas 1862.

62 In Western Kalimantan and on Banka, ca. 1860, Historisch overzicht 1898:22, 23.

63 Archief Schoute Banjoemas 1858.

${ }_{64} \quad$ Residents of several districts in 1867-68, Historisch overzicht 1898:26; M. Th. Reiche, head of the Medical Service, in his recommendation 28-6-1873 no. 994, Historisch overzicht 1898:34.

${ }_{65}$ Letter from CMS inspector Idsinga to head of the Medical Service 11-11-1876 no. 28, Historisch overzicht 1898:appendix B; Wassink 1859b:662. TBAs are generally old women (Lefeber 1994:5), just like midwives in the Netherlands between 1650 and 1865 (Van der Borg 1992:141).

$66 \quad$ Archief Schoute Preanger 1859.

${ }_{67}$ Letter from head of the Medical Service 15-1-1867 no. 90, Historisch overzicht 1898:21.
} 
surprising as these women generally became more civilised than the local women after a three-year stay in Jakarta, and thus appeared more attractive'. ${ }^{68}$ While it was known that some native midwives did live together with European men, it is going too far to state, as did the physician C.L. van der Burg (1882:374), that this was a general phenomenon that explained the closure of the school: '[T] he clinic was closed because the civilizing influence it had on the students seemed to make them more suitable as concubines for Europeans than as midwives'. Also in the investigation of the reduced welfare, it was confirmed that the midwives, 'as they had learned to read and write and become more civilised', ${ }^{69}$ found great favour with the Europeans with whom they ultimately lived.

Through their training programme and the long stay in Jakarta, the graduates not only became more attractive as concubines, they also became alienated from their fellow countrymen. The population in the residency of Banten did not harbour resentment against them so much as dread them and their superior refinement (Historisch overzicht 1898:26). And thus they preferred the familiar dukun from the village over the 'lady' from Jakarta. Along with the social distance, the physical distance in combination with the poor infrastructure often formed another reason for the natives not to turn first to the certified midwives. They usually lived in the main town, far from the rural countryside, and the population did not have money for transport. In individual cases the midwives had to take carriages at their own expense when they were called to women in labour who lived far away or in the middle of the night. ${ }^{70}$

If the population asked the certified midwives for assistance, this usually meant complications. For example, the midwife in the regency of Garut (Priangan) successfully delivered triplets in $1863 .{ }^{71}$ A complicated delivery formed a risk factor, certainly for a recently certified midwife with little experience. The native midwives in Semarang were not able to establish a practice because they were 'unlucky' to have difficult deliveries at the start of their career. ${ }^{72}$ By using the word 'unlucky' the resident indicated - probably informed by the local physician - that he in principle thought the midwives were skilled.

68 Archief Schoute Preanger 1860.

69 Onderzoek mindere welvaart 1914:86 note 1.

7o $\quad$ Resident of Semarang, Historisch overzicht 1898:15.

$7^{1} \quad$ AV for 1863, Archief Schoute Preanger.

$7^{2} \quad$ Archief Schoute Semarang. 
There were positive reports here and there, like one from Surabaya in 1859, where the native midwife Sima had skilfully helped many women, both in town and outside it. ${ }^{73}$ The municipal physician in Pekalongan, G.H. Muller, was also satisfied. Three certified midwives worked in his residency: two of them had already 'accomplished different, very difficult, unnatural deliveries of European as well as native and Chinese women with the best results' (Wassink 1859b:513). The resident of Jakarta was enthusiastic about Alida Koerong, the first certified native midwife in his town: 'This woman's behaviour is exemplary, and her skill is highly praised' (Schoute 1936:335).

Most of the certified midwives primarily had European clients, ${ }^{74}$ which had not been the intention of the training programme. Nevertheless, some, such as Priangan resident C. van der Moore, were pleased with the native midwives assisting at deliveries of European women: ' $[\mathrm{H}] \mathrm{er}$ position here can already be called a blessing, as not all appointed civil physicians are trained in midwifery'. ${ }^{75}$

\section{COMPETITION FROM THE DUKUN BAYI}

Given all the resistance against the certified midwives, the population remained faithful to the dukun bayi. The physician in Banyumas confirmed this in 1862: 'The certified native midwives have almost nothing to do; the dukun have a lot'. ${ }^{76}$ The question is how did the administrators and the midwives cope with the almost unassailable position of the dukun bayi on the medical market. Sometimes a certified midwife matched her fee to that of a dukun bayi. This matching was a local initiative rather than a government guideline, as it did not want to set a fixed fee for the midwives or for the dokter djawa. A midwife in Yogyakarta took a strategic approach to the competition with the dukun bayi. She had overcome the population's objection to 'doing nothing' during a delivery with great tact by tolerating a few adat customs and 'prejudices' as long as they did

\footnotetext{
73 Archief Schoute Soerabaja; in 1856 Sima had been working in Besuki, not her region of origin, but apparently not for long because now she was evidently working in Surabaya.

$74 \quad$ Archief Schoute Bagelen 1855; Archief Schoute Preanger 1856; Archief Schoute Banjoemas 1869.

75 AV for 1863 by resident Van der Moore; Archief Schoute Preanger.

${ }_{76} \quad$ Archief Schoute Banjoemas 1862.
} 
not harm the mother and child (Historisch overzicht 1898:26). Another way to assist the native midwives in the competition with the dukun bayi was unconditional support from an administrator. In Purwakarta this succeeded: when the native heads saw that the resident was squarely behind the midwife, they called her for assistance, after which the population followed suit (Historisch overzicht 1898:appendix A). Others also hoped that a positive attitude of the heads would convince the lower classes. ${ }^{77}$ This did not always work, as evidenced in Yogyakarta and Surakarta where both sultans employed a certified midwife for the women at court, while the common population did not use them (Historisch overzicht 1898:25). The hope of some administrators that the resistance would fade over time proved to be baseless in most residencies: in Banten the population began 'slowly to show more trust in European medicine, but as far as midwifery was concerned, they remained loyal to their tradition' ${ }^{78}$ In the residency of Bagelen the population still distrusted the certified midwives after ten years. ${ }^{79}$

\section{SUPPORT}

\section{MATERIAL SUPPORT}

Immediately after the first ten students had passed their exams, Bosch asked the government to give the graduates an allowance of 8 guilders per month; this was less than the 12 guilders they had received during their training programme. He guessed that, certainly in the beginning, it would be difficult to establish a sufficiently large practice among the population: 'At the start before they have earned any trust, they will probably be denied any form of subsistence, which will cause them, by dint of necessity, to go down paths or use means that could damage the intended goal'. ${ }^{80}$ By damaging paths or means, Bosch was probably referring to prostitution. He definitely did not assume that a midwife would be economically dependent on a husband. The request for an allowance was submitted to the Council of the Indies, which objected for fear of creat-

\footnotetext{
77 The patih in Banyuwangi and the resident of Tegal, Historisch overzicht 1898:22-3.

$7^{8}$ AV for 1870, Archief Schoute Bantam.

79 Archief Schoute Bagelen 1855, 1865.

8o $\quad$ Letter 2-11-1853 no. 907, Historisch overzicht 1898:15.
} 
ing a new, permanent cost item in the budget. In addition, the Council considered it excessive, 'If the government, after having been so generous as to give these women and the population the benefit of a good education, is now burdened for an indefinite period with supporting the students who, left to their own devices, would probably be quicker at putting their training into practice'. And if an allowance was granted, the regional administrators would have to demonstrate the absolute necessity for it. ${ }^{81}$ At the end of 1853, submission of a well-supported request for a temporary allowance was permitted. ${ }^{82}$

A few years later, in 1856, it was decided to force the regional administrators to request an allowance for the dokter djawa if he could not find a post as vaccinator or provide for himself by exercising his profession. ${ }^{83}$ Head of the Medical Service Wassink wanted to arrange the same obligation on behalf of the midwives and submitted an appropriate request to the government. According to him the midwifery course deserved a similar level of encouragement, and the midwives certainly needed the allowance just as much as the dokter djawa. ${ }^{84}$ This request went through the usual channels. The Council of the Indies called the proposal excessive and dubious in its advice. Unlike Wassink, the Council felt that the dokter djawa and the midwives should not be treated equally. The dokter djawa had to be retained for the Medical Service as they could be appointed as vaccinator whenever there was a vacancy and thus there was a reason for not abandoning them to their fate while waiting for a vacancy to arise. Regarding the midwives, the Council persisted in its opinion that the state had already done enough by providing them with a training programme. If the regional administrators could demonstrate the absolute necessity for an allowance, then it could be granted in that instance (Historisch overzicht 1898:16). In other words, the Council did not recognise any need to change the existing situation. The government adopted the advice of the Council of the Indies, and the prevailing regulations remained in force. ${ }^{85}$

But this continuous requesting of an allowance was a tedious chore

\footnotetext{
81 Advice from Council of the Indies 20-12-1853 no. XIV, Historisch overzicht 1898:15.

82 Government letter to Bosch 31-12-1853 no. 2636, Historisch overzicht 1898:15. In the letter of the adjunct-secretary of the government of 27-1-1856 no. 152a, the head of the Medical Service was authorised to do so, Bijblad 23.

$8_{3} \quad$ Resolution 11-5-1856 no. 3, Ind. Stb. 1856 no. 70.

$8_{4} \quad$ Letter 28-6-1856 no. 661, Historisch overzicht 1898:16.

85 Resolution 5-11-1856 no. 6, Bïblad 43.
} 
for a resident. In 1861 the resident of Cirebon proposed transforming the temporary allowances of the midwives in his region into allowances for an indefinite period. Wassink supported this, but the proposal did not make it past the director of Finances: 'By making the allowances more fixed in nature, one removes the stimulus that causes the woman in question to strive to improve her practice'. The government agreed with this advice. ${ }^{86}$ Wassink did not drop the matter, however. He submitted several similar requests from residents to give the allowance a more permanent character, accompanied by a passionate plea. He reminded the government of the motive for establishing the school: better midwifery assistance for the population would reduce the number of lives lost. Although the trained midwives were suited for their task, it was very difficult to build up a practice among the natives because they held tight to ancestral customs. Until this situation changed, it was necessary to support the graduates 'because otherwise they, lacking any means of subsistence, will be forced to resort to other means, far from their profession or morally repugnant. If one wants the benefit, then the necessary funds must be provided to achieve that goal' (Historisch overzicht 1898:17). Just like his predecessor Bosch, Wassink seemed to assume that the midwives would not be supported by a husband and that prostitution would tempt them if the allowance were to disappear.

Again, advice was requested form the director of Finances. He drew a comparison between the midwives and the vaccinators, who obtained a salary from the government, for which they were obliged to tour around to inoculate the population; the people were encouraged by the authorities to allow themselves to be vaccinated for free. Therefore, the midwives should also get a fixed salary in return for the obligation to travel around helping pregnant women for free, while the population would be encouraged to use this assistance. He was against providing an allowance without an obligation. From Wassink's response, it appears he felt that the director of Finances should stick to his own business: he remarked subtly that he must have forgotten that deliveries could not be planned. Wassink again explained the necessity for an allowance and pointed out the risk that they would otherwise have to support themselves by immoral means. He did take on certain elements from the director's proposal, like the obligation to provide free midwifery assistance and to involve the

86 Letter of first government secretary to head of the Medical Service 14-11-1861 no. 2853, Historisch overzicht 1898:16-7. 
regional administrators in encouraging the population to make use of it. This was ultimately the decision taken. ${ }^{87}$ It gave the allowance a more permanent and less informal character: efforts were required from both the midwives and the regional administration.

In terms of the budget, the allowance was still not properly arranged. At the end of 1867, the Indies government proposed henceforth to include a separate item in the budget for the midwives' allowance, and one for the dokter djawa. Earlier - in chapter 4 - we saw that Minister of Colonies J.J. Hasselman only agreed to these allowances so as not to delay the entire matter. ${ }^{88}$ His critical attitude was sufficient reason for the director of Education, Religion and Industry, L.J.W. de Waal, to reflect on both training programmes, as he had recently assumed the responsibility for them.

\section{IMMATERIAL SUPPORT}

From the beginning, successive heads of the Medical Service realised that along with the material allowances, immaterial assistance was also necessary if the project was to succeed. Starting immediately with the first cohort of graduates, the administrators were stimulated to encourage the population to call on the graduates (Historisch overzicht 1898:11). In 1862 the regional administrators were charged with urging the population insistently (B̈̈jblad 1209). According to the later Civil Medical Service inspector, A.G. Vorderman, only the resident in Purwakarta (Krawang) paid any attention to this. ${ }^{89} \mathrm{He}$ announced that a midwife trained and paid by the government was coming to live in Purwakarta three days before her arrival and that any woman experiencing a difficult labour was obliged to call in her assistance. ${ }^{90}$

\section{ADJUSTMENTS}

The first adjustment took place just after the training programme had started. Because apparently not one student in the first cohort could

\footnotetext{
87 Resolution 26-6-1862 no. 18, Bijblad 1209.

88 Dispatch 6-12-1867, lett. I, no. 25/1490, Historisch overzicht 1898:19.

89 As he told H.B. van Buuren, Van Buuren 1898a:31.

$9^{\circ} \quad$ Letter from Vorderman to head of the Medical Service 4-11-1876, no. 37, Historisch overzicht 1898:appendix A. Vorderman worked in Purwakarta beginning in 1-10-1876, thus he had probably heard about this measure.
} 
read, write or do arithmetic, it was necessary to include elementary education in the curriculum. Although in mid-1852 no student had yet graduated, the training programme - thanks to the positive first report - gained a structural character. ${ }^{91}$ Furthermore, the number of students was raised from 20 to $24^{92}$ as a result of the high intake of 16-17 new students in 1854 (Historisch overzicht 1898:13), which exceeded the maximum limit of 20.

\section{OBSTETRIC INSTRUMENTS}

A more radical adjustment was the granting of a case containing obstetric instruments and some medicines to the certified midwives in $1863 .{ }^{93}$ The use of instruments by midwives was a hotly disputed topic in the Dutch medical world, and many Europeans in the Indies, definitely the physicians, would have been aware of this debate. According to the Dutch law of 1818, midwives were not permitted to use instruments. They were only allowed to assist deliveries 'which took place naturally or could be brought to a successful conclusion by applying hands' (Schoon 1995:100). Although it was formally forbidden, in practice many midwives successfully applied forceps, especially if they were the only medical professional around. Student-midwives at the clinical school in Amsterdam were even trained in the use of obstetric instruments before being sent out to the Netherlands Indies (Schoon 1995:102). This was against the rules but sensible from a practical point of view because midwives in the Indies often worked in isolation.

The ban appears not to have been upheld in the Indies to any extent, either for the European or the native midwives. In the report on her activities in the period 1835-1855, the first municipal midwife in Jakarta Redeker-Pulle (1855:744-8) openly stated her regular use of forceps. The 1853 report from the head of the Medical Service, W. Bosch, to the governor-general on the final examination results of the first cohort of midwives, states: 'These women have proved on a manikin that they are capable of administering assistance, during natural and complicated de-

\footnotetext{
91 As a result of the report from the head of the Medical Service for the first 10 months (Letter 2-8-1852 no. 612), the king authorised including a fixed item in the budget for the midwives' training programme, Historisch overzicht 898:10-1.

$9^{2} \quad$ In the 1851 budget, there were 20 students, see Resolution 2-6-1851 no. 23, Wassink 1859b:657; the increase was arranged in GB 26-6-1854 no. 5; Wassink 1856:979; Historisch overzicht 1898:13.

93 GB 15-11-1863 no. 10, Büjblad 1498.
} 
liveries - if necessary, through the use of forceps' ${ }^{94}$ Probably no one was disturbed by this because these midwives were meant to work among the native population to whom the government's regulations did not apply.

Although the students learned to use forceps during their training programme, they did not have access to this instrument after graduation. In 1861 the resident of Manado requested obstetric instruments for three native midwives in his residency; they were provided. ${ }^{95}$ Subsequently, the head of the Medical Service, G. Wassink, submitted a request on behalf of all certified midwives. ${ }^{96}$ The government wondered whether the population's resistance would increase if the midwives were given instruments..$^{97}$ In his reply, Wassink wavered between the justified fear of the government about the deterrent effect of the instruments, on the one hand, and their absolute necessity in practice, on the other:

After all, it is not standard at every delivery, whether natural or not, to arm themselves immediately with instruments and display them to the women in childbirth as terrifying tools. No, the instruments are only used as is proper when there is an overwhelmingly urgent need for them; the cases of this nature, although luckily rare, are then such that the sufferers, far from showing aversion to instrumental assistance, are willing to pay that price for relief from their often severe suffering. (Historisch overzicht 1898:12)

And, he continued, even if instruments are needed for only one in a hundred deliveries, then their lack in that one delivery would be felt bitterly and could not be compensated (Historisch overzicht 1898:12). The midwives had to show their added value at difficult deliveries and thus needed to be suitably equipped.

Apparently, Wassink's argument was convincing and the recommendations positive because in 1863 general regulations were published that gave all midwives who had an allowance from the government and those in the service of the rulers of Surakarta and Yogyakarta, a case

\footnotetext{
94 Letter from Bosch to GG 21-10-1853 no. 877, Archief Schoute Batavia.

95 Letter from the resident of Manado 1-11-1861 no. 1347, Bijblad 1209.

${ }_{96}$ According to Historisch overzicht 1898:12 in letter of 23-2-1862 no. 328. This was forwarded in the Indies dispatch of July 1863 no. 549/1 to The Hague, Bïblad 1498.

97 Letter from first general-secretary 25-3-1863 no. 744, Historisch overzicht 1898:12.
} 


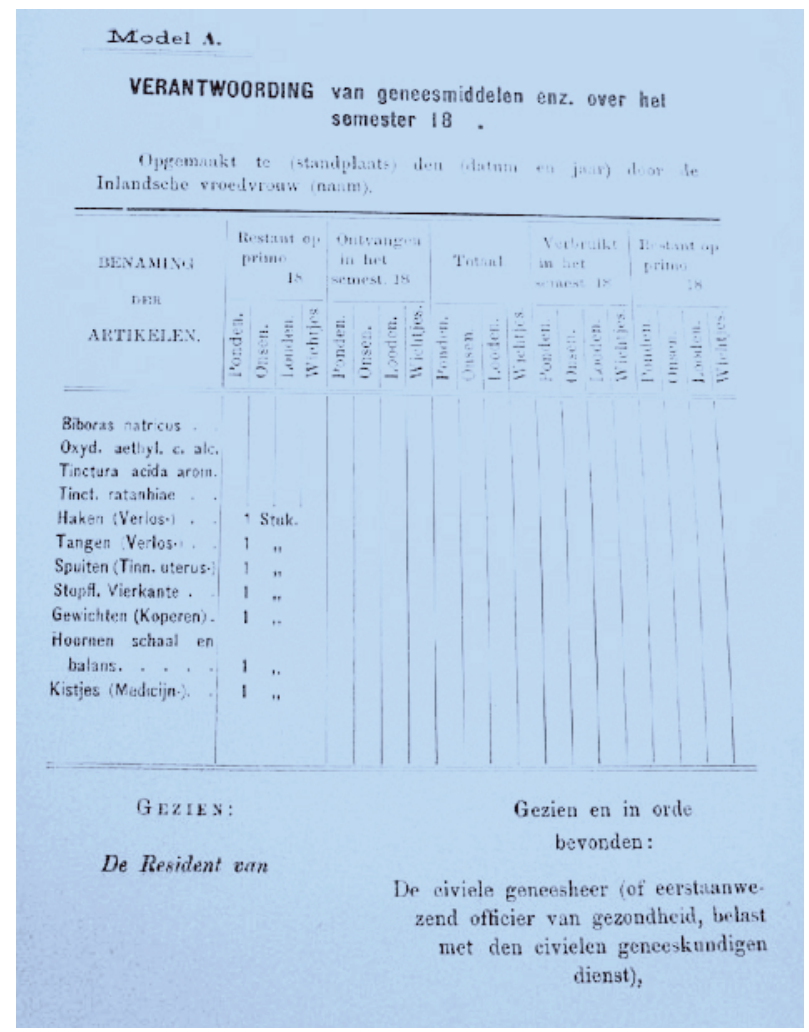

The form that the midwives had to complete (De Freytag 1899)

with some instruments and medicines. ${ }^{98}$ The few midwives who supported themselves with their own practice did not get cases, though. The contents of the case consisted of an obstetric hook, forceps, uterine syringe and several medicines. ${ }^{99}$ The midwives had to report on their use every half-year to the head of the regional administration (Bijblad 1498). Completing the form would not have been easy for women with not even one year of elementary education.

Implicitly, the government introduced a certain division of tasks be-

$9^{8} \quad$ GB 15-11-1863 no. 10, Bijblad 1498. According to KV 1863:89 the midwives in Pekalongan, Rembang, Bengkulu and Banka had already received instruments as exceptional cases.

99 Medicines like biboras natricus c aqua, tinctura rosanhiae, oxydum aethylicum c alcohole (aeth.sulp.alc), spiritus vini gallici, tinctura acida aromatica, Bijblad 1498. 
tween the dukun bayi and the native midwives by providing the medicine chest: the former assisted at normal deliveries; the second group was called in when there were complications.

\section{ADDITIONAL GIRCULAR}

In the meantime, the number of new applicants had decreased enormously. The lowest point was reached in 1865 with only two applicants. It was obvious to everyone that this situation could not continue; something had to be done. At the start of January 1866, the head of the Medical Service, A.E. Waszklewicz, sent a circular to the regional administrators, calling on them to recruit suitable students in their region. ${ }^{100}$ The circular achieved its purpose because in that year the registration was higher than ever: 26 new students from 9 residencies. ${ }^{101}$ However, Waszklewicz was not granted permission for a repeat of this successful action by the director of Education, Religion and Industry; ${ }^{102}$ thus, it did not result in a change of policy.

It seems that H.J. Zembsch-de Klemp was not asked for her opinion about any of the adjustments to the midwives' training programme. Her view may not have been of importance to European physicians given their disdain for midwives.

\section{THE GRADUATES AND THEIR TASKS, $1865-1875$}

The global picture of the position of the native midwives on the medical market was the same in the period 1865-1875 as it was ten years before. The population still called rarely on the certified midwives, ${ }^{103}$ and then only for complicated deliveries. ${ }^{104}$ The majority of the midwives could not support themselves and still received the same allowance, about 10 guilders per month, in exchange for assisting at deliveries free of charge.

\footnotetext{
100 Circular 30-1-1866 no. 167, Historisch overzicht 1898:14 note 1, 30.

$101 \quad K V 1866: 98$.

102 Request from head of the Medical Service to director of Education, Religion and Industry 2910-1868 no. 1931. In his letter 26-2-1869 no. 1644, the director of Education, Religion and Industry stated that he first wanted to wait for the outcome of his circular 4-8-1868 no. 4833 (see below), Historisch overzicht 1898:31.

103 Archief Schoute Cheribon 1868; Archief Schoute Pasoeroean 1870.

${ }_{104}$ AV for 1867, Archief Schoute Preanger; resident of Pekalongan, reply to circulars from 1867-68, Historisch overzicht 1898:26.
} 
Nevertheless, the residents regularly reported that the population considered the midwife too expensive in comparison with the dukun bayi. ${ }^{105}$ Apparently, the midwives sometimes took payment, from 60 cents to one guilder per delivery. ${ }^{106}$

Most of the residents were convinced that the natives' resistance would fade over time. A few noted that the population's limited experience with the midwives could also be ascribed to the small number of graduates (Historisch overzicht 1898:26), making them not very familiar. Only when this changed would propaganda be successful. ${ }^{107}$ The regent of Gatuh (Cirebon) stated that he could not urge the population to employ the services of the native midwives as long as there was only one midwife for the 115,000 people in his regency (Historisch overzicht 1898:27).

\section{CLIENTELE}

The midwives primarily worked for Europeans and at times for Chinese women and prominent natives. ${ }^{108}$ Europeans living outside the towns often had no European physician or midwife nearby, and thus they had to rely on a native midwife. ${ }^{109}$ Sometimes they even brought one from another residency if there wasn't one in the region. ${ }^{110}$ For a European delivery the midwife was engaged long before the due date, certainly at remote plantations, and remained there for some time as a dry nurse. All that time, often 1-2 months, they could not assist at any other deliveries. ${ }^{111}$ It is understandable that they liked working for Europeans when we see what the compensation was: 50 to 100 guilders per delivery plus full board and lodgings and gifts in the form of clothing (Historisch overzicht 1898:28). The resident of Cirebon laid a direct link between the high payment earned from Europeans and the limited efforts of the native midwives to win the trust of the natives. ${ }^{112}$ Because they earned so much from the Europeans, some even raised their fees for the indigenous

\footnotetext{
${ }^{105}$ Residents of Preanger and Batavia, Historisch overzicht 1898:28.

106 Resident of Semarang, 1867-68, Historisch overzicht 1898:27.

107 Residents of Banten, Rembang, Semarang, Yogyakarta, Priangan, Bagelen, regent of Gatuh (Cirebon), controleur in Cirebon, Survey 1867-68, Historisch overzicht 1898:26-8.

108 List of postings and locations of 54 graduates in 1867, Historisch Overzicht 1898:24-5.

109 AV for 1867 by resident C. van der Moore, Archief Schoute Preanger.

11 Europeans on the island of Belitung and in Madiun, Historisch overzicht 1898:22-3.

11 Archief Schoute Cheribon 1868; controleur of Cirebon, 1867-68, Historisch overzicht 1898:27.

112 Archief Schoute Cheribon 1868.
} 
women, which did not make them more attractive. ${ }^{113}$ In other words, the certified midwives preferred a lucrative practice among Europeans to assisting at free deliveries in the village for $f 10$ per month. And vice versa, the population preferred to call on the assistance of the dukun who were from their own villages and were satisfied with small fees.

The 50 midwives in 1873-1876 assisted at a total of 2640 deliveries in the 4-year period (Historisch overzicht 1898:46), or an average of 660 per year. This corresponds to just over 13 deliveries per year per midwife.

\section{NJI ASTIJEM AND SARIËM}

More is known about two midwives in particular, Nji Astijem and Sariëm. Three days before Nji Astijem started work in Purwakarta (Krawang), the resident had announced her arrival with cymbals and impressed on the population the need to call on her assistance in case of complications. With this support, she was able to establish a practice first among the native heads, then she rapidly won the trust of the common people. With her rough manners, this would have not been possible otherwise, according to the local civil physician A.G. Vorderman. He considered her skilled because she had successfully delivered a breech birth. Later, when the obligation imposed by the resident to call on her assistance for potentially complicated deliveries was not upheld so strictly, Nji Astijem maintained her authority over the dukun. When only the dukun was called for a complication, the husband had to report this to her. 'If he failed to do so, then she could pin the blame for this failure squarely on him, emphasising the fact that she was the government midwife'. ${ }^{114}$ She said herself that in 'the insignificant place', Purwakarta, she had more to do than all her colleagues in the entire Indies put together (Van Buuren 1898a:31-2). With the resident's support and her own expertise, this midwife established a strong position on the medical market. When the resident's support flagged, she could continue on her own.

We originally encountered Sariëm as the woman who complained to the inspector about the behaviour of her fellow students and col-

\footnotetext{
113 A midwife in Tegal, Historisch overzicht 1898:23. The residents of Batavia, Banyumas and Pekalongan called the increased payment a problem for the population, Survey 1867-68, Historisch overzicht 1898:26,28.

${ }^{114}$ Letter from Vorderman to the head of the Medical Service 4-11-1876 no. 37, Historisch overzicht 1898:appendix A.
} 
leagues. From 1867 to 1877 she worked in Kutoarjo, then she moved to Purworejo, $10 \mathrm{~km}$ eastwards (both places in Bagelen). From Kutoarjo she even assisted at deliveries in villages that lay 30 to $40 \mathrm{~km}$ away. She was clearly highly trusted because in one of the villages a colleague of hers, Sampan, had little to do (Historisch overzicht 1898:45). The notes from her training programme, which she had saved, were lost in a fire ten years after graduation (Historisch overzicht 1898:44). The fact that she reported this suggests that she still consulted them occasionally. She assisted at 30 deliveries per year among the population and another 25 with European and Chinese women. The natives paid her a fee between 50 cents and one guilder, the Europeans and Chinese $f 10$ to $f 15$ per delivery and $f 25$ if she stayed on as a dry nurse for another two weeks. In addition, she had her fixed allowance of $f 10$ per month. Poor women whom she would have helped free of charge rarely asked for her assistance (Historisch overzicht 1898:44). It is striking that Sariëm kept her allowance although she earned sufficient income from her private practice.

\section{PREPARATION FOR CLOSURE}

In 1867 the organisational structure of the Civil Medical Service changed; the final responsibility, including for the midwives' training programme, was given to the director of Education, Religion and Industry. Soon after L.J.W. de Waal became the director, he received a critical dispatch from Minister of Colonies J.J. Hasselman about the allowance for the graduates. The Indies government wanted proof of its utility and necessity. De Waal took advantage of this request to evaluate the training programme thoroughly. First of all, he asked the head of the Medical Service, A.E. Waszklewicz, for his opinion. Waszklewicz repeated once more that improvement of midwifery assistance for the population was the motive for establishing the school. He explained again that the population did not feel a need for better help, which made it difficult to establish a practice and that the graduates therefore had to depend on an allowance. Even with that prospect, it was not possible to attract enough students. To prevent the project from failing, the government had to maintain the allowance. ${ }^{115}$ De Waal seems to have disliked

${ }_{115}$ Advice from head of the Medical Service 29-2-1868 no. 388, Historisch overzicht 1898:20. 
Waszklewicz's response because he sent a survey in August 1868 to the regional administrators to ask whether it would be better to terminate the midwives' training programme. They also had to provide information about the behaviour and services of the midwives in their region. ${ }^{116}$ In February 1869 De Waal forwarded the answers from the residents to Waszklewicz. In an accompanying letter he drew a conclusion: 'Your Honour will note that in most of the residencies the midwives are not trusted by the population, and are therefore of little use. This has already been declared on many other occasions.' ${ }^{117}$ He continued that under these conditions and given the limited number of students, the training programme would have to be terminated. But before he formulated a proposal to the government, he asked Waszklewicz for his opinion (Historisch overzicht 1898:31-2). De Waal's 'conclusion' did not reflect the residents' answers. An official report from the department 30 years later spoke about De Waal's conclusions being 'incompletely and not entirely correctly represented' (Historisch overzicht 1898:22 note 1), a nice way of suggesting that the facts were distorted.

\begin{tabular}{|c|c|c|c|c|c|c|c|}
\hline Region & $\begin{array}{c}\text { Num- } \\
\text { ber }\end{array}$ & Behaviour & Suitable & $\begin{array}{l}\text { Native } \\
\text { Practice }\end{array}$ & $\begin{array}{c}\text { European } \\
\text { Practice }\end{array}$ & $\begin{array}{l}\text { Ghinese } \\
\text { Practice }\end{array}$ & Advice \\
\hline $\begin{array}{l}\text { Jakarta, } \\
\text { incl Bogor }\end{array}$ & 1 & good & good & small & yes & small & + \\
\hline Banten & 1 & good & $\begin{array}{c}\text { for } \\
\text { normal } \\
\text { delivery }\end{array}$ & yes & yes & & + \\
\hline Priangan & 6 & $\begin{array}{l}\text { little to } \\
\text { report, } \\
\text { moderately } \\
\text { virtuous }\end{array}$ & adequate & $\begin{array}{l}\text { only for } \\
\text { complica- } \\
\text { tions }\end{array}$ & yes & & + \\
\hline Cirebon & 6 & good & yes & small & yes & & - \\
\hline Pekalongan & 3 & $\begin{array}{l}\text { generally } \\
\text { very good }\end{array}$ & $\begin{array}{l}\text { generally } \\
\text { very good }\end{array}$ & small & yes & yes & + \\
\hline Semarang & 5 & good & yes & yes & yes & & + \\
\hline Bagelen & 4 & good & $\begin{array}{c}\text { for } \\
\text { normal } \\
\text { deliveries }\end{array}$ & yes & small & & + \\
\hline Banyumas & 2 & good & yes & & yes & & - \\
\hline Surakarta & 1 & good & yes & elite & yes & yes & + \\
\hline Yogyakarta & 2 & good & yes & elite & & & + \\
\hline Kediri & 3 & good & yes & small & yes & & + \\
\hline
\end{tabular}

116 Circular 4-8-1868 no. 4833, Historisch overzicht 1898:22, 31.

117 Letter 26-2-1869 no. 1644, Historisch overzicht 1898:31. 


\begin{tabular}{|c|c|c|c|c|c|c|c|}
\hline Region & $\begin{array}{c}\text { Num- } \\
\text { ber }\end{array}$ & Behaviour & Suitable & $\begin{array}{c}\text { Native } \\
\text { Practice }\end{array}$ & $\begin{array}{c}\text { European } \\
\text { Practice }\end{array}$ & $\begin{array}{l}\text { Chinese } \\
\text { Practice }\end{array}$ & Advice \\
\hline Jepara & 1 & good & yes & $\begin{array}{c}\text { elite; in } \\
\text { village } \\
\text { only com- } \\
\text { plications }\end{array}$ & yes & & + \\
\hline Rembang & 3 & $\begin{array}{l}2 \text { good; } 1 \\
\text { ex-dancer } \\
\text { immoral }\end{array}$ & $\begin{array}{c}2 \text { suitable; } \\
1 \text { not } \\
\text { trusted }\end{array}$ & & 2 yes & & + \\
\hline Surabya & 1 & good & yes & & as dry nurse & & + \\
\hline Pasuruan & 1 & good & yes & & yes & & + \\
\hline Ambon & 2 & very good & $\begin{array}{c}1 \text { very } \\
\text { suitable, } \\
1 \text { low } \\
\text { self-confi- } \\
\text { dence }\end{array}$ & & yes & & - \\
\hline Manado & 7 & good & yes & yes & & & + \\
\hline Makasser & 1 & good & $\begin{array}{c}\text { results not } \\
\text { great }\end{array}$ & small & yes & & + \\
\hline Timor & 1 & not virtuous & no & $\begin{array}{l}\text { no prac- } \\
\text { tice }\end{array}$ & & & - \\
\hline $\begin{array}{l}\text { Sumatra's } \\
\text { West Coast }\end{array}$ & 2 & good & yes & no & & & - \\
\hline Palembang & 1 & $\begin{array}{l}\text { irreproach- } \\
\text { able }\end{array}$ & yes & small & yes & & + \\
\hline Total & 54 & & & & & & $16+; 5-$ \\
\hline
\end{tabular}

Table 5.1 Opinion of administrators on the behaviour and the suitability of the graduates, their practice among the different population groups and the recommendation about continuing $(+)$ or terminating $(-)$ the training programme ${ }^{118}$

In the survey 16 of the 21 administrators were in favour of continuing the training programme and 5 against. The manner in which De Waal rearranged the outcomes to his satisfaction revealed that his request for a response from Waszklewicz was no more than a formality. This was confirmed by the fact that De Waal ordered Waszklewicz not to accept any new students on 1 May 1869 - even before his advice had arrived in anticipation of a decision on the future of the school. ${ }^{119}$ In reality, the freeze on recruitment made little difference because there were hardly any applications, but it was clear which way the wind was blowing.

Two days later Waszklewicz's advice appeared and - as expected flatly contradicted De Waal's 'conclusion'. While he did have to acknowl-

\footnotetext{
118 Answers to circulars from the first general-secretary 12-4-1867 no. 760 and from the director of Education, Religion and Industry 4-8-1868 no. 4833, Historisch overzicht 1898:24.

119 Letter 1-5-1869 no. 3458, Historisch overzicht 1898:32.
} 
edge that the midwives were not highly respected in most regions, the majority of the regional administrators wanted to retain the training programme. On the basis of the results, he hoped that the future would be brighter if the administrators could be urged to recruit enough students. It would be difficult to re-establish such an institute after it had closed, and thus he asked permission to repeat the successful action from 1866 and to appeal directly to the regional administrators to recruit suitable students. ${ }^{120}$ De Waal did not permit this. He knew that Waszklewicz's days as head of the Medical Service were limited, and he let the matter drop until his successor, M. Th. Reiche, was appointed in April 1870.

When Reiche had been in post for one and a half years, he was ordered to consider closing the midwives' training programme. ${ }^{121}$ A pause of one and a half years seems long because De Waal's mind was already made up. The interval was used for intensive discussion between the two men about the future not only of the school for midwives but also of the dokter djawa school and the veterinarian school. ${ }^{122}$ After six months Reiche produced his recommendation: the results of the training programme did not meet the original aims. The certified midwives were rarely called in by the population, and they preferred working for European women in childbirth because of the generous payment and good treatment. Reiche did not consider it necessary to continue the training programme for this group, as more and more European midwives were interested in coming to the Indies to work. ${ }^{123}$ The school for midwives must be closed. Also, the buildings were needed for the expansion of the dokter djawa school. ${ }^{124}$ Reiche fully understood that the original aim - improvement of the midwifery assistance for the population - had not been achieved. Therefore, he proposed a trial with the same manner of training as that for the European midwives in the Indies: a training on site supervised by a qualified obstetrician or midwife, which would halve the costs. ${ }^{125}$

\footnotetext{
$120 \quad$ Letter 3-5-1869 no. 839, Historisch overzicht 1898:32.

121 Letter 21-12-1872 no. 12010, Historisch overzicht 1898:30. The same letter contained the order to reconsider the dokter djawa training programme.

${ }_{122}$ De Waal referred to numerous relevant verbal discussions, Historisch overzicht 1898:33.

123 It has already been noted that the payment in the Indies was generous compared with that in the Netherlands: a month's salary in the Indies was equivalent to about a year's salary in the Netherlands.

${ }_{124}$ Verslagen vrouwenarbeid 1899:77. In this report, the MP H. van Kol stated that it was claimed that the school was closed because of unsatisfactory results, but that the real reason was that another school wanted to expand and needed the building housing the midwives' school for its expansion.

${ }^{125}$ Advice 28-6-1873 no. 994, Historisch overzicht 1898:30 and 33-5 (this recommendation also applied to the dokter djawa school).
} 
De Waal presented his recommendation on 2 October 1873 to Governor-General J. Loudon. ${ }^{126}$ Just as he earlier distorted the results of the answers from the regional administrators to the question of whether the training programme should continue, he now manipulated the origin and the moral conduct of the students and the graduates.

The majority of the students who attended the school are former dancing girls, as evident from the reports by the heads of regional administration, who even after graduating have continued to lead a highly immoral life, and thus naturally were not employed by the respectable classes of the population. Some of them, not able to resist the temptations of their previous employment, have abandoned being a midwife and become dancing girls again. (Historisch overzicht 1898:35-7)

He was being rather free with the answers from the regional administrators to the survey. But the story began to take on a life of its own. The missionary doctor H. Bervoets (1898:385) recounted years later that he heard old colonials talking about how the immoral behaviour of the students had contributed to the closure of the midwives' school. De Waal gave his predecessors another kick: 'How was it conceivable to imagine that young native women from a prominent family could be convinced to stay in the confines of the encampment, and be trained as a native midwife'. ${ }^{127}$ None of his predecessors ever mentioned young women from respectable families, so again De Waal was taking great liberties with the truth to achieve his goal. The Council of the Indies agreed on the proposal to close it (Historisch overzicht 1898:22, 37), which was then presented in November 1873 to the administration in The Hague. ${ }^{128}$ This was the response that Minister Hasselman had asked for in his dispatch almost six years earlier. ${ }^{129}$

Against all expectations, The Hague did not follow these very similar recommendations. The then minister of Colonies, I.D. Fransen van de Putte, thought there was insufficient reason to close the school. The results were definitely not satisfactory, but he did not expect any improve-

\footnotetext{
126 Advice 2-10-1873 no. 9651, Historisch overzicht 1898:35-7.

127 Advice 2-10-1873 no. 9651, Historisch overzicht 1898:35-7.

128 Indies letter of 5-11-1873 no. 1594a/25, Historisch overzicht 1898:30, 37.

129 Dispatch 6-12-1867, lett. I, no. 25/1490, Historisch overzicht 1898:19. According to the Historisch overzicht the 1875 reorganisation proposals actually formed the response to the dispatch.
} 
ment from a training programme on site: 'I would therefore recommend that the governor-general reconsider this matter, as I am convinced that one should not close an already established institution so rashly, because the desired aims have not yet been achieved'. ${ }^{130}$ At the last second the school had found an advocate in The Hague. The question is, why did the minister intervene? He had filled various posts in the Indies and undoubtedly had heard the stories about the dukun. Perhaps his political convictions were also involved; liberal politicians were the ones most interested in the welfare of the population. Unfortunately, he resigned soon afterwards, on 27 August 1874, and was succeeded by the moderate conservative, W. Baron van Goltstein van Oldenaller.

There were also changes in personnel in the Indies: in October 1873 Reiche was replaced as head of the Medical Service by B.E.J.H. Becking, and in May 1874 De Waal was replaced by C. Bosscher as director of Education, Religion and Industry. Bosscher, who was deliberating on the commission from The Hague to come up with ideas of how to counteract the decline of the school, ${ }^{131}$ heard from Becking that there were only four students at the school, who would be taking their exams in one month's time. Because there would then be no more students, he wanted to dismiss the personnel. ${ }^{132}$ Bosscher agreed to this, and in the governorgeneral's resolution of 2 September 1875 it was decided to close the school for now while waiting for reorganisation. ${ }^{133}$

\section{DRAWING UP THE BALANCE}

Between 1851 and 1872 a total of 142 students attended the training programme: 5 died, 14 were dismissed for misconduct and 20 because of unsuitability; 7 students were still at the school (Historisch overzicht 1898:14). The interim drop-out of $39(37 \%)$ is comparable with the $42 \%$ in the dokter djawa school. ${ }^{134}$ The capacity of the training programme -

\footnotetext{
130 Report from minister of Colonies to the king 1-5-1874, lett. $\mathrm{A}^{1}$, no. 31. The Indies government was informed of the denial to close the school through the dispatch from the minister of Colonies of 4-8-1874, lett. A ${ }^{1}$, no. 30/1333, Historisch overzicht 1898:37-8.

${ }^{131}$ Resolution 19-9-1874 no. 13, Historisch overzicht 1898:38.

${ }^{132}$ Letter 23-7-1875 no. 2008, Historisch overzicht 1898:38.

133 Letter from director of Education, Religion and Industry, W.A. Henny, to GG 25-8-1875 no. 9086 , Archief Schoute Batavia; Resolution 2-9-1875 no. 28, Historisch overzicht 1898:38.

${ }_{134}$ The 7 students who were still at school are omitted from the calculation.
} 
first 20, then from 1854, 24-was definitely not reached because the total number of students would have been double (282 instead of 142). ${ }^{135}$ Of the 96 women awarded a diploma, about 50 ran a practice in 1873, ${ }^{136}$ a success rate of about $50 \%$. If we look at the number of graduates, then we arrive at an average of 5 per year, and that is depressingly few. Ultimately, $60 \%$ of the students who embarked on the training programme actually did the work they were trained for. The result was thus comparable to that of the dokter djawa programme. ${ }^{137}$ At its closure in 1875, the school had produced about 100 graduates. ${ }^{138}$

Table 5.1 shows that in 15 of the 21 regions where midwives worked from 1867-1868, their services primarily or exclusively benefitted European or Chinese women; in only two regions (Bagelen and Manado) did they largely serve the population, which was the original intention of the training programme. The result was also disappointing in this sense.

\section{CONCLUDING REMARKS}

Already before 1850 attempts had been made to train native women as midwives in a Western-oriented programme. In 1850 the time was finally ripe. Just like the dokter djawa school, the midwives' training programme was a novelty: the government had not previously felt responsible for the health of the population nor invested in educating native girls. But this sounds better than the reality because for a sum of $f 10,000$ per year - a pittance compared with the enormous sums contributed by the Batig Slot in those years - the government could placate the liberals in the Lower Chamber.

The school was plagued with setbacks from the start. None of the students could read or write, so elementary education had to be added to the curriculum. The number of applications was disappointing; probably many native heads felt a certain ambivalence about a training programme so far from home for young native women, and this translated

\footnotetext{
135 In 1851-54 a maximum of $1 \frac{1}{2} \times 20=30$ students could have been admitted; in the period 1854-75, this was $1 / 2 \times 21 \times 24=252$ students.

${ }_{136}{ }^{6}$ Historisch overzicht 1898:14 specified 96 graduates in 1873. As at that moment there were still 7 students at school, the total number of graduates could very well have been the 102 given in $K V 1876$.

137 Among the midwives 50 of the 135 graduates were working, and 102 van de 256 dokter djawa.

${ }_{138} \quad K V 1876: 122$ states that the school produced 102 graduates. This would mean that of the 7 students still at school in 1872, 6 graduated successfully.
} 
into an uninspired effort to recruit students. For a long time the training programme did receive unconditional support from the heads of the Medical Service, but not from their superiors.

The position of the graduates on the native part of the markets of medical goods and services was difficult; they rarely managed to win the population's trust. The indigenous women were very attached to their familiar dukun bayi with their knowledge of the customs observed during childbirth. The government tried to ease the midwives' entry into the medical market with an allowance if they offered their services for free, but still the population hardly called on them. The availability of obstetric instruments could have improved the position of the midwives on the medical market because they would have been better equipped for complications than were dukun bayi, but it could also have widened the gap with the population. In addition, difficult deliveries presented a risk, certainly for midwives at the start of their career: after an unsuccessful delivery, it would have been even harder to build up a practice. We cannot estimate whether the support of administrators, European and/ or native, would have increased the public's trust. We know of only one example: Nji Astijem, who had the backing of the resident. With few exceptions, the native midwives did not manage to secure positions on the native markets of medical goods and services. This can be explained on the one hand by the strong position of the dukun bayi, and on the other by the attractive possibilities for the graduates on other midwifery markets, primarily involving European women. There they were paid much better, and their assistance was appreciated. The question is whether the government intended to employ the graduates as intermediaries to introduce Western midwifery to the population. It was indeed decided that the native midwives would return to their regions of origin, where they knew the language and customs, preconditions for roles as intermediaries. But they were not accepted by the population because of their youth and sometimes 'Western' behaviour, and thus they could not fulfil a role as intermediary.

It was proposed several times to improve the midwifery assistance among the population by training the dukun bayi. According to the health officer J.G.X. Broekmeyer (1856:41), this resulted in failure: 'Unsuccessful attempts have already been made to teach the dukun something, but it seems they are afraid to lose their good name by learning even a bit of European medicine'. That Broekmeyer had hit upon an 
important point was illustrated by a dukun from the Priangan, the only one who ever attended the school for midwives. Very soon after completing her training programme, she took up her former profession again. ${ }^{139}$ This illustrates that for a dukun bayi, it didn't make any sense to undergo training in Western midwifery; rather it was counterproductive.

The disappointing results were a reason for the top administration not to invest any more in the training programme or its graduates. The school was closed, and another approach was chosen in which the primary cause of the failure was glossed over, the lack of trust among the population in Western midwifery assistance. 